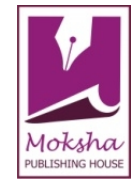

\author{
Review Article \\ www.ijrap.net
}

\title{
COMPARATIVE STUDY OF SAMBHASHA IN CHARAK SAMHITA WITH SYMPOSIUMS HELD IN MODERN ERA
}

Rajpreet Singh ${ }^{1 *}$, Veenu Malhotra ${ }^{2}$, Rimpaljeet Kaur ${ }^{3}$, Shashikant Bharadwaj ${ }^{4}$

${ }^{1}$ M.D. Scholar, Department of Ayurveda Samhita and Siddhanta, Babe Ke Ayurvedic Medical College and Hospital, Daudhar, Moga Punjab, India

${ }^{2}$ Professor, Department of Ayurveda Samhita and Siddhanta, Babe Ke Ayurvedic Medical College and Hospital, Daudhar, Moga, Punjab, India

${ }^{3}$ Assistant Lecturer, Department of Kaya-Chikitsa, Desh Bhagat Ayurvedic Medical College, Mandi Gobindgarh, Punjab, India

${ }^{4}$ Ayurvedic Medical Officer, Rajiv Gandhi government Ayurvedic Hospital, Paprola, Himachal Pradesh, India

Received on: 13/04/16 Revised on: 10/05/16 Accepted on: 22/05/16

*Corresponding author

E-mail: rr22859@gmail.com

DOI: $10.7897 / 2277-4343.073100$

\begin{abstract}
Knowledge of medical sciences and arts only is not sufficient to qualify a medical practitioner but he is expected to be acquainted with a number of other sciences which are likely to bear some relation to life. A full conception of science will never be attained by the knowledge of only a part of it. If a man be well read in Charak but ignorant of even the name of diseases described in Sushrat and other works or if he be not wanting in practical methods but wholly ignorant of Charak what can such a poorly equipped man do to relieve the ailment of patients. Three methods to obtain the knowledge are Adhyayana (Study), Adhyapana (Teaching) and Sambhasha (participating in debates), from which the last method 'Tadvidya Sambhasha' (debate between experts of same field) is being discussed in detail. In the ancient period the method is known as Sambhasha, as the time changed from ancient to modern era it takes the form of Symposium. The methodologies and purposes of both are similar along with the discussion methods while following the rules and regulations with the introduction of new techniques and advancement of technology. Today many milestones achieved in the field of Ayurveda by organizing the committees like Chopra and Pandit committee to debate for the promotion of education and practice of Ayurveda in country.
\end{abstract}

Keywords: Sambhasha, Symposium, Discussion, Experts

\section{INTRODUCTION}

Ayurveda is the oldest and traditional therapy of India which has been used since $2^{\text {nd }}$ century B.C. To obtain the theoretical and practical knowledge of Ayurveda one should choose the text of medicine depending upon his competence to undertake light or serious type of work ${ }^{1}$. In Charak Samhita it is mentioned that a person can acquire or learn the noble qualities from his enemies without having the sense of jealousy ${ }^{2}$. The three methods to obtain the knowledge of text are Study, Teaching and Participate in debates. "Bhishak Bhishaja Saha Sambhashet" means one physician discusses a problem with another physician to solve the problem ${ }^{3}$ and clear the doubt is a 'Tadvidya Sambhasha'. It could also be used to solve the war issues between the nations and family disputes also. Sambhasha is taking the form of Symposium, Seminar, Conference, Summit, Congress, Colloquium etc. to discuss a problem or a topic to explore the thoughts of intellectual people and to give a relevant conclusion. Rigveda $^{4}$ and Nyaya darshan also gives the clues about Sambhasha. Symposium is the gathering of number of experts of same field and discussion on a concern topic to get the relevant conclusion. As time changed, the techniques has changed from Pathshalas, Guru Shishya Parampara to large symposium halls with the use of high level writings, pictures, models, ppt's, OHP and web seminars for creating interest in audience and making event more attractive. Sambhasha and Symposium are similar with a common objective to dispel the doubt regarding any topic and throw light on the unclear topic that's why this study is required in order to explore the relevance of Sambhasha in the present time and to derive a relation between principles of Sambhasha mentioned in Charaka Samhita with Symposiums in modern era.

\section{CONCEPTUAL STUDY}

\section{Concept in Charak Samhita}

Knowledge of one subject is not enough for a scholar. One should have the knowledge of many other text of the same subject. Critical study is one custom to evaluate the subject through thorough understanding, profound discussion and interpretation. The intellectual excellence of physician based on study, teaching and participate in debate ${ }^{5}$.

\section{Need for Sambhasha}

In the past due to Aapta knowledge (knowledge of past, present and future) of Rishis they had vast knowledge of all the things in this world; they also learn and recite the teachings of Gurus by heart, not through the books or texts. But in modern era due to short life span and less memorizing power of man one could not acquire the vast knowledge of each and every subject related with field. So the method of discussion with experts of same field solves the purpose to achieve the thorough knowledge of subject. These experts are filling the space of Aapta purusha (person having knowledge of past, present and future) present in ancient period.

Sambhasha is the discussion of a physician with another physician or the experts of one branch should discuss about a topic related to their subject. 


\author{
Origin of Sambhasha \\ सम्भाषणम्-ल्क), (मं+भाष十ल्युट)कथनम् . आलापनम् .
}

\section{History of Sambhasha}

The Sambhasha is also said as Vaada (discussion) in many texts. In 44 'Vaada marga pada' (logical terms used in debate) the first one is Vaada, the concept of Vaada is derived from the "Nyaya darshan ${ }^{7}$. It is a debate in a hostile manner with an opponent following the laws of shastra (text) i.e. it should have five Avayavas, Paksha (in favour) and Pratipaksha (in opposing side) both lay down on the basis of Parmana (parameters for evidence) and Tarka (logic reasoning).

\section{Importance of Sambhasha}

1. Enjoyment with the knowledge

2. Promotion of speaking power

3. Spreading fame, command and confidence over previous topic

4. Know many new things about a topic; develop scholarship and skill of defeating the opponent ${ }^{\mathbf{8}}$.

\section{Two types of Sambhasha}

Sandhaaya Sambhasha (friendly discussion) continue with the person possesses scientific knowledge, power of argument and counter argument, correct knowledge, not rejoice by defeating opponent, describe answers to the questions with confidence, polite with opponent etc?.

Vigrahya Sambhasha (hostile discussion) continues with the person by examining the good and bad qualities of an opponent. On the basis of these qualities opponents are classified into superior, equal and inferior. One should not participate in debate with superior opponent and immediately defeat the inferior by tricky procedures e.g. not learned with long aphorisms, not experienced with difficult aphorisms, dull with same type sentences carry different meanings etc ${ }^{10}$.

There are logical terms to be acquainted by the debaters also known as the 44 Vaada marga pada which decides the victory of a debater over the opponent. These are mostly consists of Five Avayavas, Six Padarthas, Vaada, Sthapana, Six Parmanas, Pratisthapana, Uttar, Siddhanta, Sanshaya, Paryojana, Jigyasa, Vyavasaya, Sambhava, Anujojya, Annujojya, Anuyoga, Pratyanuyoga, Vakyadosha, Vakyaparsamsa, Cchala, Ahetu, Attitkala, Upalambha, Parihara, Pratigyahani, Abhayanugya, Hetvantra, Arthantra and Nigrahasthana ${ }^{11}$. If the opponent is using the 12 type of Nigrahasthana in his discussion and losses his proposition without explaining the relevant reasoning and evidence in its favour he will be considered as defeated in debate.

There are seven Sambhasha's in Charak Samhita, In the end of discussion Lord Atreya explained the objective/motto by giving the evidence and examples in the context of topic in the end of discussion. The Hypothesis is proposed in the beginning of Sambhasha and after that the discussion according to hypothesis continue between the Rishis who had travelled from faraway places without any call from Gurus. They himself visited to Guru to achieve the excellence and for the well being of all living creatures in the world.

\section{Concept of Symposium}

Symposium is a meeting or a conference for the discussion of a topic, especially a meeting at where several speakers discuss a topic before an audience ${ }^{12}$. In ancient Greece it meant "to drink together". It is forum for men of respected families to debate, plot or reveal with others. It refers in English because participants might compete in rhetorical contests where multiple speeches are made. The symposium has some similar words like conference, meeting, seminar, colloquium, discussion, chat, forum, talk etc. On the basis of definition, purpose of discussion, objectives, rules and regulation, organizing committee etc. each term is differentiated from "symposium",

Symposium is small scale conference at which several speakers discuss a topic before audience in a single day in academic setting. Conference is usually large prearranged meeting for consultation and takes several days, or researchers deliver their research to audience. It need not be academic in nature all the time. Seminar is a forum for a lecture of an expert for an audience to educate and clear the doubts, usually held group of 10-15 individual participate actively. The speaker present and discuss through combination of visual materials, interactive tools or equipment and demonstration. Congress held once a year between leaders of field to highlight achievements, notable results in that field. Colloquium is to present a most popular and less technical topic to well educated but unspecialized audience. It is simple, informal academic conversation or meeting to present the progress of research work. Summit is conducted by high ranking officials or decision making. Forum encourages round table discussion ${ }^{14}$.

\section{Types of Debate}

1. Parliamentary debate

2. Debate between candidates of high officials: It is typically more restrictive than traditional format. In the campaigning session heavily dominated by television advertisement, talk radio they still provide lesser opportunity for citizens to see and hear the major candidate side by side.

3. Competitive debate: Two teams compete against each other and judged the winner by criteria based upon concept of content, style and strategy ${ }^{15}$.

\section{Format of Symposium}

Divide participants into two groups. Assign them into affirmative and negative team. Ask each participant to prepare brief for each position. Each team prepares three arguments, each argument contains three statements and each statement carries three quotes. For each quote, one sentence summary must be provided with source and photocopy of quote ${ }^{16}$.

\section{Rules and regulations}

Director is appointed by organizing committee which prescribes resolution, composition of teams, speaking time and procedural regulations. A moderator is appointed to maintain order and enforce the rule, three adjudicators are appointed for judging the discussion. Teams sit behind the table or chairs adjoining a moderator. Each team has equal time to speak about topic which is allotted 10-20 minutes by timekeeper. Each session contains three sections i.e. opening statement, rebuttal and summary. Moderator introduces the debater and grant the right of speak. Speaker preface his remarks to moderator and acknowledge the audience before starting discussion. Speaker should not breach the rules with irrelevant statement. He should stick to the resolution being proposed. Negative team must propose alternative relevant definitions of resolution during first speech. The judges make the decision on the basis of resolution and evidence and interpretation of the speeches and terms made by both the teams ${ }^{17}$.

In the medical health communication the Symposiums are beneficially to provide knowledge and awareness about related health problems, prevalence of new diseases and protection from the epidemic conditions to the patients and general population of that area ${ }^{18}$.

\section{Advancements in Symposium}

The teacher and student interaction in Guru Shishya Parampara, Pathshalas (classrooms) to achieve the knowledge based upon 
personal interactions. The arising of logical reasoning behind the concept by students, Acharya's started the process of discussion with experts known as Sambhasha. Now the format of Sambhasha takes the form of Symposium with the introduction of new techniques i.e. High level writings, Pictures or Flipcharts, after that Models, Objects and Specimen. In the same way Demonstrations followed by Films and Charts ${ }^{18}$. After that Poster presentation and then Computers change the methods of presentations. Computer changes the method through Power point presentations which further takes on OHP's in Symposium halls. Now, one can communicate with other debater through the Web conferencing/Webinars ${ }^{19}$ which also lowers the travelling costs and saves lot of time.

\section{DISCUSSION}

The discussion between the experts includes the methods to set objective in the starting of Symposium. The penetrating points which are to be discussed with a group of experts must be emphasized; along with this the brief points of discussion are opened for the small group or selected scholars but not for whole the audience being participated. The third major point is funding for organize a symposium by the organizations. These processes were equally followed by the Acharya's in the Samhita period for discussion. The experts of medical field participate in discussion in Sambhasha but Symposium provides opportunity to the experts of other fields also to share their view points with the concern knowledge of medicine to provide advancements in medical field e.g. the bio engineers discuss various new technologies with doctors to achieve the milestone for the development of new machines for diagnosing the problem and provide better line of treatment in emergency. The advancements for presenting the research work and discussion about topic change the scenario in symposium halls.

\section{CONCLUSION}

From the above discussion it may be concluded that on the basis of definition, methodology, objectives, purpose, characteristics, principles, points of discussion (penetrating and brief), rules and regulation, questions raised during discussion and evidences provided at the end by speaker proves the similarity between both Sambhasha and Symposium. The introduction of new techniques and advancement in technology changes the scenario of presentation and discussion method in this modern era. Three methods of obtaining knowledge along with utility and importance of Sambhasha were discussed in introduction. The conceptual study of Sambhasha mentioned in Charak Samhita was described in the first phase of article. In the second phase, Symposium was defined in detail with rules and regulations followed, new advancements in technology changes the method of discussion and presentation. Discussion shows the similarity and difference between the methodology of Sambhasha and Symposium. It was concluded in the end that the ancient Sambhasha takes the form of Symposium with the introduction of new techniques in modern era.

\section{REFERENCES}

1. Harishchandra Singh Kushwaha, Vimana Sthana chapter 8 verse 3, Charak Samhita with Ayurveda Dipika Ayushi
Commentary, Varanasi (India), Chaukhambha Orientalia, 2011, p. 655

2. Harishchandra Singh Kushwaha, Vimana Sthana chapter 8 verse 14, Charak Samhita with Ayurveda Dipika Ayushi Commentary, Varanasi (India), Chaukhambha Orientalia, 2011, p. 661

3. Harishchandra Singh Kushwaha, Vimana Sthana chapter 8 verse 15, Charak Samhita with Ayurveda Dipika Ayushi Commentary, Varanasi (India), Chaukhambha Orientalia, 2011, p. 661

4. Rigveda 1.89 .1

5. Harishchandra Singh Kushwaha, Vimana Sthana chapter 8 verse 1, Charak Samhita with Ayurveda Dipika Ayushi Commentary, Varanasi (India), Chaukhambha Orientalia, 2011, p. 655

6. Raja Radhakanta Dev Bhaduren, Shabdakalpadrum, Jalalpurmafi, U.P., Nag publishers, 1987, Vol 5, p. 285

7. Mahamahopadhyaya Satish Chandra Vidyabhusana, verse 1/2/1, Nyaya Sutra of Gautam, Panini office, Bhadurganj, Allahabad, Bhuvaneswari Ashrama, 1913, Vol 8, p. 14

8. Harishchandra Singh Kushwaha, Vimana Sthana chapter 8 verse 15-16, Charak Samhita with Ayurveda Dipika Ayushi Commentary, Varanasi (India), Chaukhambha Orientalia, 2011, p. 661

9. Harishchandra Singh Kushwaha, Vimana Sthana chapter 8 verse 17, Charak Samhita with Ayurveda Dipika Ayushi Commentary, Varanasi (India), Chaukhambha Orientalia, 2011, p. 661

10. Harishchandra Singh Kushwaha, Vimana Sthana chapter 8 verse 18, Charak Samhita with Ayurveda Dipika Ayushi Commentary, Varanasi (India), Chaukhambha Orientalia, 2011, p. 662

11. Harishchandra Singh Kushwaha, Vimana Sthana chapter 8 verse 27, Charak Samhita with Ayurveda Dipika Ayushi Commentary, Varanasi (India), Chaukhambha Orientalia, Varanasi, 2011, p. 665

12. http://www.freedictionary.com/symposium: www.google.com: accession on26 Dec 2015

13. http://www.wikipedia.org/wiki/symposium: www.google.com: accession on 26 Dec 2015

14. http://www.researchgate.net: www.google.com: accession on29 Dec 2015

15. http://www.wikipedia.org/wiki/debate: www.google.com : accession on 3 Jan 2016

16. http://www.nwabr.org/../debate.pdf.teaching background

17. http://www.debatingsociety.ca/materials/rules: www.google.com: accession on 5 Jan 2016

18. K. PARK, Preventive and Social Medicine, Jabalpur Madhya Pradesh (India), M/s Banarsidas Bhanot Publishers, $20^{\text {th }}$ Edition, 2009, p. 765-768

19. http://www.teachingenglish.org.uk/article/... www.google.com: accession on 10 Jan 2016

\section{Cite this article as:}

Rajpreet Singh, Veenu Malhotra, Rimpaljeet Kaur, Shashikant Bharadwaj. Comparative study of Sambhasha in Charak samhita with symposiums held in modern era. Int. J. Res. Ayurveda Pharm. May - Jun 2016;7(3):5-7 http://dx.doi.org/10.7897/22774343.073100

Disclaimer: IJRAP is solely owned by Moksha Publishing House - A non-profit publishing house, dedicated to publish quality research, while every effort has been taken to verify the accuracy of the content published in our Journal. IJRAP cannot accept any responsibility or liability for the site content and articles published. The views expressed in articles by our contributing authors are not necessarily those of IJRAP editor or editorial board members. 